Title: Talking about liveness: responses of young people in the TheatreSpace project

Corresponding author: Penny Bundy, Associate Professor, School of Education and Professional Studies, Griffith University, [Mt Gravatt Campus, Griffith University. (Affilitation - Griffith Institute for Educational Research)

Postal address if needed: 176 Messines Ridge Road, Mt Gravatt, Queensland 4122, Australia. Telephone: 0737355620. Email p.bundy@griffith.edu.au

Bundy, P.(as above) one-sentence bio - Associate Professor Penny Bundy is a member of the Applied Theatre team at Griffith University and Program Convenor of the Bachelor of Arts in Applied Theatre.

Donelan, K. one-sentence bio - Associate Professor Kate Donelan is Principal Fellow, Arts Education, Melbourne Graduate School of Education, University of Melbourne.

Ewing, R. one-sentence bio - Robyn Ewing is Professor of Teacher Education and the Arts and Associate Dean (Academic) Faculty of Education and Social Work, University of Sydney.

Fleming, J. - Dr Josephine Fleming worked as a researcher on the TheatreSpace project and is currently working on a project examining the impact of arts education on academic motivation and achievement, both at the University of Sydney.

Stinson, M. Dr. is a member of the Applied Theatre team at Griffith University and Program Convenor of the Bachelor of Education (Secondary) for the School of Education and Professional Studies.

Upton, M. one-sentence bio -Meg Upton lectures in Drama Education at Deakin University and is completing a $\mathrm{PhD}$ at the University of Melbourne

Short Abstract: (68 words)

This paper draws on the TheatreSpace project to address the question: what can we learn about the experience of liveness in a theatre event from the young people who attend? The discussion considers six aspects of the experience: the comfort or discomfort of presentness; performer vulnerability, risk and uncertainty; proximity to the live action; perceptions of realness; a sense of relationship with the actors; and intensity of engagement.

\title{
Talking about liveness: Responses of young people in the TheatreSpace project
}

This paper draws on analysis of interviews with over 500 young people who attended theatre performances as part of the Australian TheatreSpace project. The paper opens with a brief description of the project before turning to focus on one small but critical aspect of the findings. Asked what they valued in a theatre experience, a significant number of young people spoke about 
liveness. The paper addresses the question: what are the key points/ideas about liveness that we can learn from listening to the young people? Our discussion includes a consideration of: the comfort or discomfort of presentness; performer vulnerability, risk and uncertainty; proximity to the live action; perceptions of realness; a sense of relationship with the actors; and intensity of engagement. A brief consideration of the implications for teachers and theatre providers concludes the paper.

\section{Project Description}

From 2008 to 2011, a team of researchers from the Universities of Sydney and Melbourne and Griffith University, supported by an Australian Research Council Linkage grant, collaborated with some of the major flagship theatre companies, venues and arts funding organizations in three Australian states to investigate "what attracts, engages, and sustains the participation of young people as theatre audiences of major cultural providers". We also sought to understand what factors might exclude the participation of young people. Our thirteen industry partners (Sydney Opera House; Sydney Theatre Company; Bell Shakespeare; Arts New South Wales; the Australia Council; The Arts Centre, Melbourne; Malthouse Theatre; Melbourne Theatre Company; Arena Theatre Company; Arts Victoria; Queensland Performing Arts Centre; Brisbane's Powerhouse; and the Queensland Theatre Company) provided access to their chosen productions, cash and in-kind support. Ethical consent to conduct the research was sought from and granted by each of the Universities and the relevant education authorities in the three states.

\section{Research design}

The research design comprised two strands. The first of these was a survey administered to year 10 and 12 students in 19 schools, the purpose of which was to provide baseline data about theatre attendance. Nearly 900 students completed these surveys. A selection of the survey respondents were then interviewed by telephone up to three times over the following three years. The second (and main qualitative) part of the study involved 21 case studies: two case studies for each of the partner organizations. A further case study involving a number of individual works was completed for the World Theatre Festival (Powerhouse: 2010). Most of the plays were main house productions intended for a general audience. One of the works, that targeted young audiences (Shape of a Girl) was presented by two of our partners and formed the basis of two case studies. A full list of the theatre events studied is included in Table 1. 


\section{Table 1}

\begin{tabular}{|c|c|c|c|}
\hline No & Title of Production & Company Participant & Date of Case Study \\
\hline 1 & The Importance of Being Earnest & Queensland Theatre Company & 23 October 2008 \\
\hline 2 & $\begin{array}{l}\text { Anatomy Titus Fall of Rome: A } \\
\text { Shakespeare Commentary }\end{array}$ & Bell Shakespeare & 28 October 2008 \\
\hline 3 & Yibiyung & Malthouse Theatre & 9 November 2008 \\
\hline 4 & Fake Porno & Brisbane Powerhouse & 30/31 January 2009 \\
\hline 5 & The Removalists & Sydney Theatre Company & 19 March 2009 \\
\hline 6 & $\begin{array}{l}\text { Goodbye Vaudeville Charlie } \\
\text { Mudd }\end{array}$ & Arena Theatre Company & 27 March 2009 \\
\hline 7 & The Shape of a Girl & Sydney Opera House & 19 May 2009 \\
\hline 8 & The Shape of a Girl & Arts Centre Melbourne & 26 May 2009 \\
\hline 9 & God of Carnage & Melbourne Theatre Company & 9 September 2009 \\
\hline 10 & The True Story of Butterfish & Brisbane Powerhouse & 9 October 2009 \\
\hline 11 & Up Jumped the Devil & $\begin{array}{l}\text { Queensland Performing Arts } \\
\text { Centre }\end{array}$ & 30 October 2009 \\
\hline 12 & World Theatre Festival & Brisbane Powerhouse & 13 February 2010 \\
\hline 13 & The Beauty Queen of Leenane & Sydney Theatre Company & 9 March 2010 \\
\hline 14 & King Lear & Bell Shakespeare & 30 March 2010 \\
\hline 15 & Moth & Arena Theatre Company & 26 May 2010 \\
\hline 16 & The Threepenny Opera & Malthouse Theatre & 10 June 2010 \\
\hline 17 & Fat Pig & Queensland Theatre Company & 8/24 June 2010 \\
\hline 18 & Moth & Sydney Opera House & 26 May 2010 \\
\hline 19 & Dead Man's Cell Phone & Melbourne Theatre Company & 5 August 2010 \\
\hline 20 & This Kind of Ruckus & Arts Centre Melbourne & 26 August 2010 \\
\hline 21 & Wicked $^{1}$ & $\begin{array}{l}\text { Queensland Performing Arts } \\
\text { Centre }\end{array}$ & 9/15 February 2011 \\
\hline
\end{tabular}

For each case study, researchers attended one performance (either negotiated with or nominated by the partner organization) and collected qualitative and quantitative data from participants. The quantitative data included a survey of responses from most of the young people attending the event. The survey sought a range of information such as age, gender, postcode, language spoken at home as well as knowledge about the past cultural participation of the respondents. This was completed prior to seeing the work and therefore did not include information about the experience of the particular performance they were attending. The qualitative component, which informs this paper, involved semi-structured interviews conducted individually, or in small groups immediately post-show or, where this was not possible, at the school locations within a few days of the theatrical event. The purpose of these interviews was to seek to understand the way young people experienced the play, the performance and the event as a whole. Where possible, further follow up

\footnotetext{
${ }^{1}$ At the time of writing this article, analysis of the Wicked case study was not complete so it was not included in the overall analysis.
} 
interviews were conducted with these same young people two weeks, then six months and twelve months later.

The project participants included young people attending theatre alone, with their families, carers or friends and as members of school groups. Initially, our focus was on young people aged between 14 and 25 but this was later extended to include the responses of people up to 30 years of age. In addition, key stakeholders (e.g. teachers, arts industry workers) were interviewed.

\section{The analysis process}

Data from each of the case studies were separately analyzed and detailed individual reports were completed and presented to the respective partners. The collected case study reports were then cross-analysed through the lens of the following 11 questions:

1. What factors influence whether a young person chooses to attend or not attend a performance event?

2. How do the performance choices of teachers and caregivers influence the theatre going experience of young people?

3. What effects do venue and performance context have on young people's attendance at the event?

4. What effect do venue and context have on young people's experience of the event?

5. To what extent does membership of particular socio-cultural groups impact on attendance at a performance event?

6. To what extent does membership of particular socio-cultural groups impact on young people's engagement with the performance event?

7. What is the impact of a young person's education on his/her experience of the performance event?

8. Is theatre literacy a significant factor influencing a young person's response to the performance event?

9. What elements of a theatrical experience engage young people?

10 . What do young people respond to and value in the theatre experience?

11. What kinds of performance events are post-schooling young adults attracted to and is this different from the kinds of performance events that engaged them as school students?

This paper focuses on one of the themes that emerged in response to question 10: What do young people respond to and value in the theatre experience? Asked what they valued in the theatre 
experience, a significant number of young people spoke about liveness. Recognizing this in 20 of the 21 individual case study reports ${ }^{2}$ we returned to the initial interview data (545 interviews) and identified all of the instances where young people used the word liveness or spoke about being present in the same space at the same time as the performers. We then reanalyzed these responses, asking the question: "What are the key points/ideas about liveness that we can learn from listening to these young people?"

After analysing the data in this way, we returned to the literature focusing on liveness. Would the findings of others help us to understand this concept further? Would our understanding confirm or extend what had already been documented?

Two quite distinct theoretical approaches to the discussion and understanding of liveness are evident in the literature. Auslander's interesting 2002 work discusses mediatization and looks at (and challenges) the nature of liveness itself. What we sought though was work that discussed the way people experienced liveness as members of a theatre audience. We found a limited range of research and writing from within the theatre literature. Authors who wrote about the experience of liveness included Barker (2003), Radbourne, Johanson, Glow, \& White (2009) and Reason (2004, 2006, 2010a, 2010b). Barker's work, in Wales (UK), focuses on a comparison of young people's responses to a live performance of the play Crash with their responses to a film version of the work. Radbourne, Johanson, Glow, \& White conducted five focus group interviews to investigate adult audience experience in response to two music concerts and three theatre productions. This Australian study sought to explore the hypotheses "that audience experience is an appropriate and important measure of quality in the performing arts, particularly in relation to re-attendance" (p. 16). Liveness emerged as an important component of their respondents' experiences. The most prolific published researcher in this area, Matthew Reason (based in the UK), has conducted a number of small studies that explore the experiences of liveness of primary and secondary school aged children. His discussion of liveness as "presentness" (being in the same space, at the same time as the performers and other audience members) aligned with the way the young people in our study used the term 'liveness'.

\section{Experiencing Liveness}

In the following sections we discuss some of the characteristics that young people frequently identified as key components of their experience of liveness. These include: being in the audience;

\footnotetext{
${ }^{2}$ The Wicked case study was excluded as previously mentioned.
} 
the comfort and discomfort of presentness; performer vulnerability, risk and uncertainty; proximity to the live action; perceptions of realness; a sense of relationship with the actors; and the intensity of engagement. (The order in which they are presented is not intended to imply a hierarchy.) Where relevant we highlight the similarities between the findings of our study and those of the other authors mentioned above. Finally we conclude by drawing attention to some implications for teachers, and theatre providers.

\section{Being in the audience: The comfort and discomfort of presentness.}

Analysis of the interview data indicates that being aware of other audience members around them and being aware of themselves as members of the audience both contribute to young people's experiences of liveness and impact on the nature of their engagement with the performance. For some people, usually those who are inexperienced theatre-goers, this awareness is characterized by discomfort. However, it is part of the pleasure of the experience for those who are comfortable and confident being audience members at live theatre events.

Reason (2004 p.19) uses the term "mindfulness of the presence of the audience" to discuss the responses of two young people who stated that they liked watching audience members responding. He states that it is not so much an awareness of the presence of other spectators, but more particularly, an interest in and awareness of how different audience members are responding to the performance. This focus on observing the responses of other audience members was noted in the TheatreSpace study responses to The Importance of Being Earnest (October, 2008), Goodbye Vaudeville Charlie Mudd (March, 2009), God of Carnage (September, 2009), Shape of a Girl (May, 2009), and The Removalists (March, 2009).

The study conducted by Radbourne, Johanson, Glow, \& White (2009) concluded that the main reason spectators gave for differentiating their experience of the live and recorded arts was that at the live event they experienced a sense of being part of a "shared, communal audience experience" (p. 23). Upton (2010) also notes that the communal environment is part of the experience of the live event. For her, this is particularly so for an experience shared with peers. Young people in a focus group discussion following Goodbye Vaudeville noted:

When you're in the theatre there's much more of a human element I think because, not only have you got the people on the stage, but the people in the audience there seems to be more, sometimes, interactions. So you feel more of a group experience rather than an isolated one. (female, 25 years) 
I think you're live there, with live bodies means that you can't ever quite escape that feeling of connection and communication. (female, 20 years)

Being part of a shared communal audience offers the spectator a sense of connection to others. For Radbourne, Johanson, Glow, \& White (p. 21) this was one of three types of interaction which they grouped under the umbrella term "collective engagement". They claimed that this occurred at a range of live arts events. Respondents in the TheatreSpace study indicate that this is not particular to the arts but might also be experienced for example at a sporting event. For example, following a performance of Butterfish, one young person stated:

...I must say a lot of people agree with the contact, feeling connected to what they're seeing but I guess everyone is different. I know a lot of my friends, they all like sort of going to theatre or sporting events and get into that whole team pride thing but yeah I guess it's all just sort of being there in the moment regardless of what it is. (female, late 20s)

O’Farrell (1994, p. 50) draws on the concept of 'communitas', central to Victor Turner's work (1982), to explain "a deep sense of collective unity" for participants within a drama workshop and a theatre space. Dolan (2006) also applies 'communitas' to the experience of being in an audience where a person feels at one with others and therefore part of a larger collective whole. She says the feeling includes being "part of the whole in an organic, nearly spiritual way; spectator individuality becomes finely attuned to those around them, and a cohesive if fleeting feeling of belonging to the group bathes the audience" (Dolan, 2006, p. 166). Heather Lilley (2010, p. 35) makes the same claim suggesting that feeling part of a larger whole, experiencing the sense of community is a valued part of the theatre experience.

A sense of collective engagement was certainly true of the experiences of young people in a number of the case studies we conducted. They made comments such as: “You're sharing this, I don't know 100 to 1,000 other people and they're all there, you're all there laughing as one, you're crying as one" (God of Carnage, student, public high school); and, “...I like to be part of an audience that's tired at the end of it, but exhilarated" (GoodbyeVaudeville Charlie Mudd, female late 20s). Thus, a feature of the live audience experience seems to be the sense of connection it offers audience members who feel comfortable in the theatre space.

Conversely a sense of discomfort can both characterize and impact on audience experience and engagement at a live theatre event. Feelings of discomfort and exclusion were experienced when young people found the content of the work too confronting or alien. For example, one 22 year old 
female, commenting upon her experience as part of the audience of The Removalists notes, "I did not really feel free to react and betray my feelings because I was ashamed" (The Removalists, female 22 years) or when they perceived that other people had an understanding of how to respond that was not available to them. Following their experience of attending The Removalists a number of young people spoke about their discomfort, indicating that they felt that they had not dressed correctly, that they did not belong, or that they could not understand the humour while others around them did. Some were unhappy that the light spill, which meant they could be seen, inhibited their responses. Others indicated unease because they felt other audience members had a deeper understanding of the themes being explored. These young people felt excluded and were conscious of being outsiders. For example:

I thought other people were getting stuff more than I was, which they probably were. But even, they were even enjoying it more than I was, because they knew what to look for or they were used to that sort of performance. (The Removalists, male, 21 years)

Spectators' perceptions that they have been unable to find a way to read a performance text can increase their self-consciousness and feelings of vulnerability. This in turn reduces engagement. Radbourne, Johanson, Glow, \& White (2009, p. 25) suggest that this perception can change if spectators believe that other audience members are feeling the same way as them. Similarly Reason (2004, p. 21) suggests that spectators experience pleasure when their own responses are affirmed by other people's apparently similar reactions.

\section{Performer Vulnerability, Risk and Uncertainty}

Analysis of the responses of the young people in the TheatreSpace study also indicated that performer vulnerability, uniqueness, risk and uncertainty were sought after and admired qualities of a live theatre event. Frequent comments were made about the notion that something might go wrong, that the actors were exposed, that they lacked the protection of the film shoot and that each performance would be different. Young people commented that the willingness of the actors to expose themselves to the possibility of making a mistake in front of the audience made them seem more human. This was valued as a positive quality of the live experience. Furthermore, young people who had studied or engaged in theatre making themselves were more aware of the centrality of vulnerability, risk and uncertainty as important components of their experience of live theatre. 
Blau (1992, p. 23) claimed that human 'liability' is central to the experience of live performance: “...stage fright, lapses of memory, a stomach ache on stage, a coughing fit, unscripted laughter" are all recognized by spectators as a part of our shared human frailty. In the TheatreSpace study, one young person commented:

I like that, and you know, if they do make a mistake, I don't know, I just like the uncertainty of it. I like the uncertainty of it because it's always uncertain like see stuff happen on stage you're like oh that was not meant to happen but it's still fun. (Butterfish, female, 20 years)

Reason (2006, p. 232 and 2004, p. 22) and Radbourne et al (2009, p. 24) recognized similar qualities in the responses of audience members in their studies. The possibility of something going wrong is part of the thrill of live performance. It is not so much the occurrence of the mistake but its possibility that is recognized by spectators as a component of their experience of liveness. They take pleasure from the perception that a mistake is possible, and also take satisfaction in attempting to spot the error and the recovery from it.

This delight in seeking to spot the error was accompanied by a sense of respect and admiration for the performers. Sometimes the admiration related to the risk the performers were deemed to be taking. At other times the admiration related to recognition of the complexity of what the actors did, and how they did it. This included commentary on the skill of the actors in the moment of reaction.

\section{Proximity to the Live Action}

Respondents in the TheatreSpace study usually described physical proximity as a desirable element of their live theatre experience. The closer to the action a person was, the more involved they felt. In response to Beauty Queen of Leenane, one teacher noted that Small Wharf 2 theatre "is such a good theatre for engaging a young audience. You are not far from the action. The actor is in your face in the flesh" (teacher, regional high school). In response to The Importance of Being Earnest, one young person stated, "Yeah. You get involved and it makes you feel like you're actually there and you get like really interested and all that" (male, year 9 student, independent school). Comments about Butterfish included: "I like being close to the play itself", "seeing interaction in real-life", "real time interaction", "feeling like you're peeking in on people's lives", "being there in the moment", "seeing human interaction in real life, in real-time"(Butterfish, audience members in their 20s). 
On the other hand, some responses indicated that the distance from the stage contributed to a feeling of distance from the action. "We were sitting in the last three rows right at the very back and that was very difficult for the kids because they were so far away. They had to really concentrate on what was going on to really get some of those nuances and to feel the performance." (God of Carnage, Teacher, inner city college).

Quite often the word "immediacy" was used when people were discussing proximity. In response to Fake Porno, The Removalists and Goodbye Vaudeville Charlie Mudd people referred to the power of immediacy and the way it encouraged a more intense emotional experience. In response to other performance events this intensity of response was noted in other ways. For example, in response to The Importance of Being Earnest, the comment was, "It's more thrilling because it's actually happening in front of you" (male, year 9, public high school).

Following The Removalists, reference was made to the closeness increasing attention to the work. One respondent described the experience as "intimate", claiming that this encouraged engagement. Similarly one of the young performers in Moth recalled her own earlier experiences of attending theatre: "I enjoyed seeing people present a story to me in a kind of very personal and intimate way and in real time - they're actually there. That was very exciting". As long as young people feel comfortable and confident as audience for a particular work, their sense of relationship with the actors and the work is heightened when the physical proximity between them and the work is minimized.

However, being close to the action when the action is deemed to be too confronting can reduce engagement and alter the quality of response. For example, being close to the action in Yibiyung and Beauty Queen of Leenane resulted in some of the spectators "feeling confronted". A similar statement was made about Up Jumped the Devil: "seeing people in the flesh is more confronting" (female, early 20s).

Interest in the work was heightened by the sense of proximity to the live interactions in the performance space. Following Butterfish one person stated, "I probably enjoy it more than film. I'm not sure what about it. I guess it's the watching the interaction - interacting close at hand" (female, 20s). Another person added: "Yeah, that's more real" (female, 20s). In response to The Importance of Being Earnest, one young person commented:

Like being in the theatre it's live and you're right there with them and you're with a group of people that really enjoy - just they want to go see this. I mean you'll get the odd - it's live 
and they're right there. If you wanted to you can like touch them, but like playing the Xbox or the - yeah - completely different. (female, year 9 student, public high school)

When a work is experienced at close hand in this way, the spectators' attention is drawn to the humanity (and probably vulnerability) of the performers. Typical comments include: "In the theatre it's real life. You're watching it there in front of you." (Yibiyung, female student, independent school) and "I think it's the experience, because, I love the idea that you are right there in the experience, and you can see like the sweat lying there on the actors forehead and like the spit flying from their mouth" (Beauty Queen of Leenane, male, year 12 student, independent senior college).

Being physically present in the same space as the performers appeared to either increase emotional response to the work or heighten spectator awareness of their own emotional response. For example, in reaction to Yibiyung one person stated, "You feel like that really happened to her" (female school student, independent school), while a response to Beauty Queen of Leenane was, “... it's there. You can feel it" (male, year 12 student, independent senior college). This included awareness of being able to smell the rain and the porridge bubbling on the stove. Similarly, comments on the experience of Up Jumped the Devil included: "The immediacy and the emotion that the actors put into it"; "you have always been in the moment all the time"; "seeing people in the flesh is more confronting".

\section{Perception of Realness}

The "realness" of the live theatre experience was a feature noted and admired by many young people in the TheatreSpace study. Their attention was drawn to any occurrence on stage that heightened their awareness of the actors being "real people". They noticed (often with delight) actor sweat and spit (The Removalist, Moth) or running water and lighted lamps (Beauty Queen of Leenane). Their attention was drawn to the broken arm of an actor (Moth). Recognition of the realness "out there" made them feel more like they were part of that realness. Following Up Jumped the Devil one young person referred to this quality as being "more 4D". Other terms used by young spectators to describe their experience of the quality of "realness" across a number of the case studies included "rawness"," immediacy", and "grittiness". Barker's respondents also noted qualities related to the realness of the live work as being significant to their experience (2003, p. 24) and offering similar responses to those offered in our study, they identified that they had the possibility of touching the actors, that they could smell them. 
In Reason's 2006 study the young people also indicated that the "realness" of the live theatre event was significant to them. Reason (2006, p. 234) stated, "film was perceived as more realistic than theatre; but that in contrast the stage was seen as more real than the screen largely because 'there's actual real people on stage'." Reason (2006, p. 235) believes that his young respondents made this claim because they experienced greater tension, emotion, and energy in response to the live work rather than what they experience at other times when viewing film. The presence of the performers and other spectators in the same place and time contributes to this perception. In all of these studies, the perception of realness heightened spectator focus and attention to the work. As one young person stated, "you pay more attention because they're real people”.

\section{A Sense of Relationship with the Actors}

Many of the TheatreSpace research participants perceived a strong relationship between themselves and the work. They experienced a sense of connection between the actor (not the character) and themselves within a diverse range of performances from different companies and different venues. Various comments indicating this included: "It's like you are in the performance sometimes" (Shape of a Girl, NSW); "you feel more part of it"; "you get drawn in and feel a sense of connection to the actor" (Shape of a Girl, Vic ); " it almost feels interactive even though it is not; a sense of being transported (Titus); “you feel like a part of it almost; it almost feels like that you're there - so it's happening to you" (Yibiyung); "in the theatre you become a part of the story" (Moth);

"you feel a sense of the connection to the actors on stage and there are emotions and feelings in that sense of connection" (Up Jumped the Devil). One young person commented that, "Because the experience itself being actually, depending on which play you're in, in as an audience, you're almost in the play with the actors, you're right at the action, they can make eye contact with you, they can look at you, they can reference you in the audience" (The Importance of Being Earnest, male, year 11 student).

The young people valued the live theatre experience because they were in the same space as the actors, with the possibility that the actors could directly interact with them. As individual audience members they share a live, dynamic, and potentially interactive performance space.

The thing that I loved as well is that I saw on the news Hugh Jackman and Daniel Craig were in a play and they were playing two New York cops and someone's phone went off in the audience and Hugh Jackman stayed in his character and goes, you gonna turn that off? (American accent) And you wouldn't have that in a movie, and the whole audience, was just, but he stayed 
completely in character, interacted with the audience member, you know, and you would never get that in any other form of entertainment. (Butterfish, female, 20s)

Other mediums, it seems, lack a sense of relationship between the performer and spectator, "there is a relationship, a real relationship, like a now relationship between what's happening up there and what's happening in the auditorium" (World Theatre Festival Response, male, 20s).

In Radbourne et al's study (2009, p. 25) three forms of interaction were identified as contributing to spectator enjoyment of the live theatre performance. Two of these, "communication between performers and the audience," and "communication from the audience to the performers" also indicate a perception of a relationship between the actors and the audience on the part of spectators. Comments made by audience members and cited in Reason's work (2006, p. 231) support this.

\section{Intensity of Engagement}

Young people who spoke to us in the TheatreSpace study referred to the intensity of their reactions as a quality of their experience of liveness. Unprompted, they often compared their responses to live theatre, film and real life events, indicating that they reacted differently to confronting events on the stage than they might do if the same event was to be witnessed on screen. Young people who attended Shape of a Girl (NSW) noted that they were shocked by the behaviour and use of obscenities that they witnessed directly on stage, claiming that they would not have reacted this way had they been viewing a film. Similar comments were made by young people who had attended The Removalists. In response to Yibiyung comments included: "I think that's why it is so confronting because it was right there in your face and you believed in what was happening and it was just like 'wo', like that's crazy" (female, year 11 student).

Awareness of the intensity of their experience as spectators at the live theatre event was evident in many of the case studies. In a group interview following the Sydney production of a Shape of a Girl people commented on the intensity of their responses to the live action: "you can see the emotions better; you can feel them; you could see all her emotions; a sense of excitement as you watch, that you don't get from other things" (female students, year 9, independent school). In response to the Victorian production of the same play, interviewees noted that "the live experience is powerful". In response to The Importance of Being Earnest we were told that "It's more thrilling because it's actually happening in front of you." "Feeling the energy, the excitement, the buzz" were expressions offered in response to this play. 
While I think that some action movies can be pretty insane with CGI and such, seeing you know it [theatre] live, even though they stab people and make it look realistic and stuff, it's sort of nice because you can feel the energy and excitement that goes into it. It's like more of a buzz than seeing a movie, where you can just be like. Yeah, this isn't actually happening. (The Importance of Being Earnest, male, year 11 student, independent school)

Other audience members for The Importance of Being Earnest felt that the intensity of the theatre experience was greater than the impact they received from watching the movie version of the play. One respondent added, "you get more into it". Another said, "I think seeing something live on stage has a much bigger impact than just a movie on the screen". Young people discussing their experience of a Shape of a Girl in Victoria described it as "more real, more emotional". One person went so far as to state that you "feel like a part of it, you feel like you're actually experiencing it." A similar response was made in response to Moth, "Yeah, it was really intimate and like a small space. You would really like it. In a big one you can't really feel that much... so close you feel like you're in the story" (female, year 10 student, independent school). In response to Beauty Queen of Leenane one person stated: "on stage you're part of the moment, you can't really ignore it" (male, year 12 student, independent college). Another said, "Theatre involves the audience more than TV does, captures our attention better" (female, year 10 student, independent school).

In this project, one young person asserted that their gaze at a live theatre event is more intense and more focused. When the gaze is more intense it has more potential to focus the attention of the spectator on the ideas and questions raised by the work. In response to a Shape of a Girl (NSW) one respondent stated, "Because it's there in front of you (it) forces you to confront something you might normally just take for granted or ignore" (female, year 9 student). In discussing the different responses of people to film and the live work, Barker (2003, p. 22) suggests that people go to film with a "relatively detached general interest" but that we expect theatre to be meaningful. He (Barker, 2003, p. 24) considers that the need to work to understand a theatre performance is a quality of the live experience that spectators can savour. His own belief is that the spectator at a live event wants and expects to be challenged but that the film-goer does not necessarily do so.

\section{Concluding Remarks}

Our study indicates that liveness (being present in the same space at the same time as the performers) is a valued aspect of theatre attendance for young people. This paper has outlined some of the aspects of liveness that young people identified as being important. Their comments 
also drew our attention to aspects of the live theatre experience that can inhibit their engagement. In drawing this paper to a close we would like to briefly highlight some of the implications of this for teachers and theatre providers.

The comfort or discomfort that young people experience when they attend live theatre events significantly impacts on their experience. This paper has highlighted some of the major factors that can cause increased self-consciousness and feelings of vulnerability for spectators at live theatre events. Awareness of the factors that create comfort and discomfort allows educators and arts providers to put in place strategies that provide opportunities to minimize feelings of exclusion and maximize feelings of engagement. Any work that teachers, theatre providers, parents and care givers can do to encourage the theatre confidence and comfort of young people is likely to enhance enjoyment and engagement.

Higher levels of confidence and comfort in the theatre environment also provided greater opportunity for young people to connect to the human themes being explored in the theatre work and a greater possibility that they will simultaneously feel a sense of shared humanity with their peers, teachers, families and other audience members. A positive shared theatre experience offers opportunity for further connection amongst and between those who experience this together.

Teachers (and other caregivers) need to judge how confronting a particular work is likely to be to their students. Rather than avoid such work, appropriate preparation and other strategies can be implemented that will help the students to feel comfortable. Consideration may be given to increasing the distance of the selected theatre seating to the stage. However, for the young people who are likely to feel confident in the space, selection of seating in close proximity to the stage is likely to enhance engagement.

Young people value the presence of real people (actors) and respect and admire their vulnerability. The perception of vulnerability resulted in a stronger experience of the tension and energy of the work. Their experiences were also enhanced by experiencing a sense of relationship with the actors. Appropriately structured opportunities to meet the actors 'live' preshow might further enhance this sense of connection.

\section{References}

Auslander, P. (2002). Liveness: Performance in a Mediatized Culture (Taylor and Francis e-library 2002 ed.). London: Taylor and Francis. 
Barker, M. (2003). Crash, Theatre Audiences, and the Idea of 'Liveness'. [electronic article]. Studies in Theatre and Performance, 23(1), 21-39. doi: 10.1386/stap.23.1.21/0

Blau, H. (1992). To All Appearances: Ideology and Performance. New York \& London: Routledge.

Dolan, J. (2006). Utopia in Performance. Theatre Research International, 31(2), 163-173.

Lilley, H. (2010). Vital Contact: Creating Interpretive Communities in a Moment of Theatrical Reception. About Performance, 10, 35-50.

O'Farrell, L. (1994). Education and the Art of Drama. Geelong, Victoria: Deakin University Press.

Radbourne, J., Johanson, K., Glow, H., \& White, T. (2009). The Audience Experience: Measuring Qulaity in the Performing Arts. Intenational Journal of Arts Management, 11 (Spring 2009)(3), 16-29.

Reason, M. (2004). Theatre Audiences and Perceptions of 'Liveness' in Performance. Particip@tions, $1(2)$.

Reason, M. (2006). Young Audiences and Live Theatre, Part 2: Perceptions of Liveness in Performance Studie in theatre and performance, 26(3), 221-241.

Reason, M. (2010a). Asking the Audience: Audience Researchand the Experience of Theatre. About performance, 10, 15-34.

Reason, M. (2010b). The Young Audience: Exploring and Enhancing Children's Experiences of Theatre. Stoke on Trent, Sterling, USA: Trentham Books.

Upton, M. (2010). Articulating the Theatre Experience: Frames of Response. NJ, 33(2), 57-66.

\footnotetext{
i The research team included Chief Investigators Professor John O’Toole, Associate Professor Michael Anderson, Associate Professor Penny Bundy, Professor Bruce Burton, Associate Professor Kate Donelan, Professor Robyn Ewing, Dr. John Hughes, Mr. Noel Jordan, Associate Professor Angela O’Brien, Dr. Christine Sinclair, Dr. Madonna Stinson.
} 